\title{
東日本大震災における応急仮設住宅の空気環境に関する調査研究 A STUDY ON INDOOR AIR ENVIRONMENT OF TEMPORARY HOUSES AFTER THE GREAT EAST JAPAN CALAMITY
}

\author{
柳宇*1, 吉野 博 ${ }^{* 2}$, 長谷川兼一 ${ }^{* 3}$, 東 賢一 ${ }^{* 4}$ \\ 大澤元 毅*5, 鍵 直 樹*6, 猪野玩也*7 \\ U YANAGI, Hiroshi YOSHINO, Kenichi HASEGAWA, \\ Kenichi AZUMA, Haruki OSAWA, Naoki KAGI \\ and Takuya INO
}

\begin{abstract}
This paper describes the measured results on carbon dioxide concentrations in 27 temporary houses in summer and winter in Sendai city after half a year of the Great East Japan Earthquake. The carbon dioxide concentrations in temporary houses were high generally. In summer, the median value in 7 temporary houses $(26 \%)$ and $75 \%$ tile value in 20 temporary houses (74\%) exceeded 1,000 ppm. Moreover, concentrations in 17 residences (63\%) exceeded 5,000 ppm, and highest was about 11,000 ppm. In winter, the median value and 75\% tile value were both higher than that in summer respectively. Although ventilation is effective to reduce the indoor carbon dioxide concentrations, temporary house where air volume is small, when an open type combustor was used in winter, indoor carbon dioxide concentration might exceed $10,000 \mathrm{ppm}$.
\end{abstract}

Keywords: Great East Japan Calamity, Temporary house, Indoor air quality, Carbon dioxide, Ventilation 東日本大震災，応急仮設住宅，室内空気質，二酸化炭素，換気

\section{1 はじめに}

2011 年 3 月 11 日に発生した東日本大震災は, 阪神・淡路大震災, 新潟中越沖地震と異なり広域に被害をもたらしたため, 復興住宅の 建設が完了するまでに長期間を要し，被災者らは未だに応急仮設住 宅（以後仮設住宅と略す）での生活を送っている。今後 30 年以内に 東海・東南海・南海で M8.5 クラスの地震が発生寸る確率が 60 〜 $87 \%$ とされている1)ことから，これに備える上でも現状の仮設住宅にお ける空気質の実態を把握し, 問題があればその対策を検討する必要 がある。

直近 20 年間に起きた大規模な震災についてみると，1995 年 1 月 17 日に起きた阪神・淡路大震災後に立てられた仮設住宅戸数は 49,681 戸, 入居者数は 47,911 世帯, 2004 年 10 月 23 日に起きた新潟 県中越地震後に立てられた仮設住宅戸数は 3,460 戸，入居者数は 9,649 人であった。阪神・淡路大震災後の仮設住宅での入居期間は 1995 年 2 月 2 日 2000 年 1 月 14 日, 新潟県中越大地震後の仮設住 宅での入居期間は 2004 年 10 月 23 日〜2007 年 12 月 31 日となって おり 2)，被災者らは長期間，仮設住宅で過ごすことを余儀なくされ ている。これまで, 仮設住宅の室内環境について, 温熱環境に関す る調査結果はいくつか報告されているが3), 仮設住宅内の空気質に
関する詳細な調査報告は殆ど見当たらない。

そこで, 本研究では仮設住宅の室内空気環境を明らかにするため に，宮城県内にある仮設住宅を対象に 2011 年夏期と 2012 年冬期に 詳細な調査を行った。木報では室内空気污染の代表指標または換気 量の指標とされる二酸化炭素濃度の測定結果について述心゙るほか, 二酸化炭素濃度の上昇要因と住まい方との関係について検討を行っ た。

\section{2 研究方法}

\section{1 調査対象住宅と測定方法}

\section{(1) 夏期測定}

筆者らは仙台市内にある 40 件の仮設住宅について, 住まい方の聞 き取り調査, 温熱環境, 真菌污染，化学物質污染の実態に関する継 続的な調查を行った ${ }^{4 \sim 10)}$ 。本報では，2011 年 8 月末と 10 月初旬か ら行った宮城県内の 40 件住宅のうち, 二酸化炭素濃度測定器を設置 できた 27 件 (8月末 15 件, 10 月初旬 12 件, 何れも家族の滞在時間 が長い居間に設置）の室内二酸化炭素濃度を中心に報告する。測定 に用いた測定器は温湿度 $\mathrm{CO}_{2}$ レコーダ $\mathrm{MCH}-383 \mathrm{SD}$ （Lutron 製，以 後 $\mathrm{CO}_{2}$ センサーと呼ぶ) であった。測定間隔は 10 分間とし，8 月開
*1 工学院大学建築学部 教授·博士(公衆衛生学, 工学)

*2 東北大学 名誉教授. 工博

*3 秋田県立大学 教授・博士 (工学)

*4 近畿大学 講師·博士 (工学)

*5 国立保健医療科学院 統括研究官・博士 (工学)

*6 東京工業大学 准教授・博士 (工学)

$* 7$ 東北大学大学院 修士課程
Prof., School of Architecture, Kogakuin University, D.P.H., Dr. Eng.

Prof. Emeritus, Tohoku University, Dr. Eng.

Prof., Akita Prefectural University, Dr. Eng.

Lecturer, Kinki University, Dr. Eng.

Research Managing Director, National Institute of Public Health, Dr. Eng.

Assoc. Prof., Tokyo Institute of Technology, Dr. Eng.

Graduate School, Tohoku University 


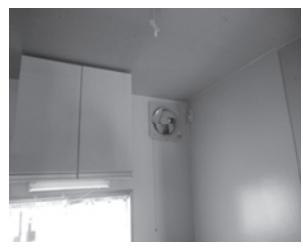

写真 1 台所換気扇

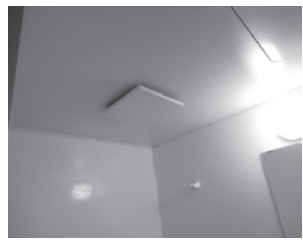

写真 2 浴室換気扇

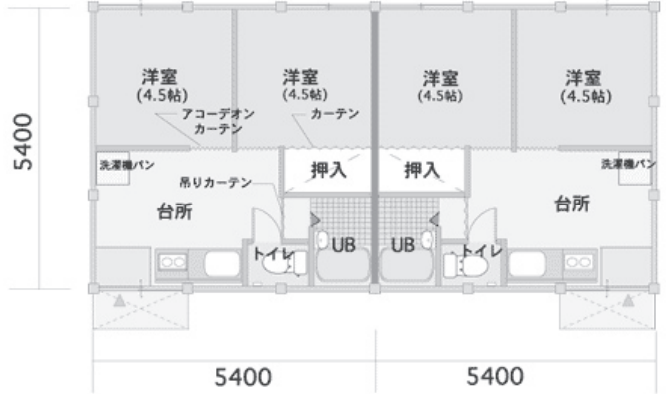

図 1 2LDK の間取りの例（プレハブ建築協会）

始と 10 月開始の測定の何れにおいても 11 月中旬に回収した。なお, 仮設住宅の換気設備と間取りの例を写真 1,2 と図 1 に示す。台所に はプロペラ扇（定格風量 : $450 \mathrm{~m}^{3} / \mathrm{h}$ )，トイレ及び浴室には天井埋め 込み型換気扇（定格風量それぞれ： $85 \mathrm{~m}^{3} / \mathrm{h}, 75 \mathrm{~m}^{3} / \mathrm{h}$ ）が備えられて いる。なお, トイレと浴室のファンの運転は連動していない。

(2) 冬期測定

2011 年 12 月下旬から 2012 年 3 月下旬の間, 2011 年夏期に測定し た 27 件のうち,さらに協力が得られた 9 件について, 前述したもの と同様の方法で室内温湿度と二酸化炭素濃度の連続测定を行った。

\section{$2.2 \mathrm{CO}_{2}$ センサーについて}

本研究に用いた $\mathrm{CO}_{2}$ センサーには，国際規格化されている二酸化 炭素濃度の測定法に適用されている非分散型赤外線吸収法 (non-dispersive infrared spectrometry, NDIR) ${ }^{11)}$ を用いている。なお, 本センサーはゼロガスとスパンガスによる校正が難しい構造となつ ているため, 本研究では予め全ての $\mathrm{CO}_{2}$ センサーについて同原理で, ゼロガスとスパンガスによる校正済みの IAQ モニター (カノマック ス製）を標準計測器とし， $\mathrm{CO}_{2}$ センサーの校正を行った。さらに, 本センサーは高濃度の二酸化炭素の測定に適しているかどうかを確 認するために，陰圧のチャンバー（ドラフトチャンバー）内でドラ イアイスによりチャンバー内の二酸化炭素濃度を高めて $10,000 \mathrm{ppm}$ まで測定できる UM-300（光明理化学工業製，NDIR 法）との同時 測定を行った結果，本センサーが高濃度の二酸化炭素を測定可能で あることが確認された（図 2）。

\section{3 結果}

\section{1 換気扇の運転状況}

表 1 に夏期と冬期に行った聞き取り調査の結果のうち換気運転状 況の一覧を示す。換気扇を終日運転する住宅（No.9），終日停止する 住宅（No.26）がある一方, 必要に応じて運転する住宅が最も多かっ たことが分かる。なお，表 1 に示したのは聞き取り調查時点での回 答であり，その後の居住者の換気行動を保証するものではない。

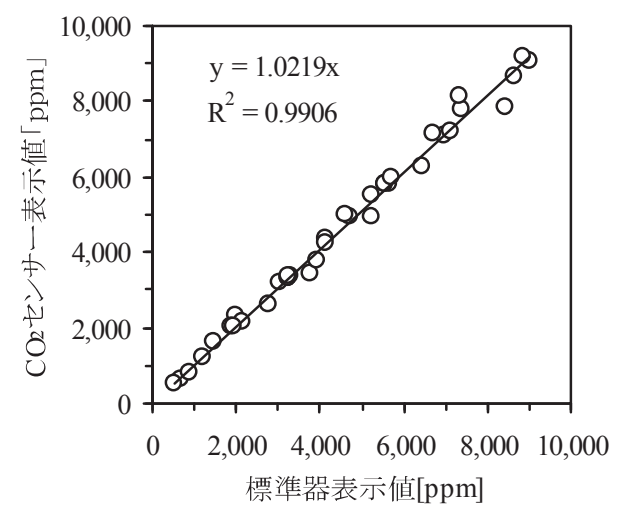

図 2 本センサーと UM-300 の比較

表 1 測定対象住宅の概要と換気運転状況

\begin{tabular}{|c|c|c|c|c|}
\hline \multirow{2}{*}{$\begin{array}{c}\text { 住宅 } \\
\text { ID }\end{array}$} & \multirow{2}{*}{ 間取り } & \multicolumn{3}{|c|}{ 換気扇運転状況 } \\
\hline & & 台所 & 浴室 & トイレ \\
\hline 2 & 2DK & 停止 & 必要時 & 必要時 \\
\hline 3,23 & $2 \mathrm{DK}+2 \mathrm{DK}$ & 必要時 & 必要時 & 必要時 \\
\hline 4 & 2DK & 必要時 & 終日 & - \\
\hline 6 & 2DK & 必要時 & 日中停止 & 終日 \\
\hline 8 & 2DK & 必要時 & 終日 & 終日 \\
\hline \multirow{2}{*}{9} & \multirow{2}{*}{ 2DK } & 終日 & 終日 & 終日 \\
\hline & & 終日 & 終日注2 & 終日 \\
\hline 21 & 2DK & 殆どつけない & 必要時 & 必要時 \\
\hline \multirow[t]{2}{*}{22} & \multirow[t]{2}{*}{ 2DK } & $\begin{array}{l}\text { 日中空開け } \\
\text { 夜間運転 }\end{array}$ & $\begin{array}{c}\text { 日中空開け } \\
\text { 夜間運転 }\end{array}$ & $\begin{array}{c}\text { 日中窓開け } \\
\text { 夜間運転 }\end{array}$ \\
\hline & & 終日 & 終日 & 不明 \\
\hline \multirow{2}{*}{25} & \multirow{2}{*}{ 2DK } & 終日 & 2 時間位 & 使用後30分 \\
\hline & & 必要時 & 終日 & 終日 \\
\hline 26 & 2DK & 停止 & 停止 & 停止 \\
\hline 29 & 2DK & 必要時 & 必要時 & 必要時 \\
\hline \multirow{2}{*}{36} & \multirow{2}{*}{ 2DK } & 必要時 & 必要時 & 必要時 \\
\hline & & 必要時 & 必要時 & 必要時 \\
\hline 44 & 2DK & 必要時 & 必要時 & 必要時 \\
\hline 45 & 2DK & 必要時 & 必要時 & 必要時 \\
\hline 53 & 2DK & 必要時 & 必要時 & 必要時 \\
\hline \multirow{2}{*}{58} & \multirow{2}{*}{ 2DK } & 必要時 & 必要時 & 必要時 \\
\hline & & 必要時 & 必要時 & 必要時 \\
\hline 64 & $2 \mathrm{~K}$ & 調理時 & 終日 & 終日 \\
\hline \multirow{2}{*}{81} & \multirow{2}{*}{ 1DK } & 必要時 & 必要時 & 必要時 \\
\hline & & 必要時 & 必要時 & 必要時 \\
\hline \multirow{2}{*}{83} & \multirow{2}{*}{ 2DK } & 必要時 & 必要時 & 必要時 \\
\hline & & 必要時 & 必要時 & 必要時 \\
\hline 91 & $3 \mathrm{~K}$ & 必要時 & 必要時 & 必要時 \\
\hline 102 & 2DK & 帰宅時15分 & 必要時 & 必要時 \\
\hline 103 & $2 \mathrm{~K}$ & 必要時 & 必要時 & 停止 \\
\hline \multirow{2}{*}{111} & \multirow{2}{*}{ 2DK } & 必要時 & 必要時 & 必要時 \\
\hline & & 必要時 & 必要時 & 必要時 \\
\hline \multirow[t]{2}{*}{115} & $3 \mathrm{~K}$ & 必要時 & 終日 & 終日 \\
\hline & & 終日 & 終日 & 終日 \\
\hline 117 & $1 \mathrm{DK}$ & 必要時 & 必要時 & 必要時 \\
\hline 122 & $2 \mathrm{DK}$ & 必要時 & 必要時 & 必要時 \\
\hline 127 & 2DK & 必要時 & 終日 & 終日 \\
\hline
\end{tabular}

注 2 : 事後電話での確認では, 寒いときに換気扇を止めることが分かった。

\section{2 夏期の測定結果}

図 3 に夏期に行った測定で得られた二酸化炭素濃度 (10 分間測定 值，以後同）を示す。図 3 には 4 等分值（最大值，75\%夕イル值， 


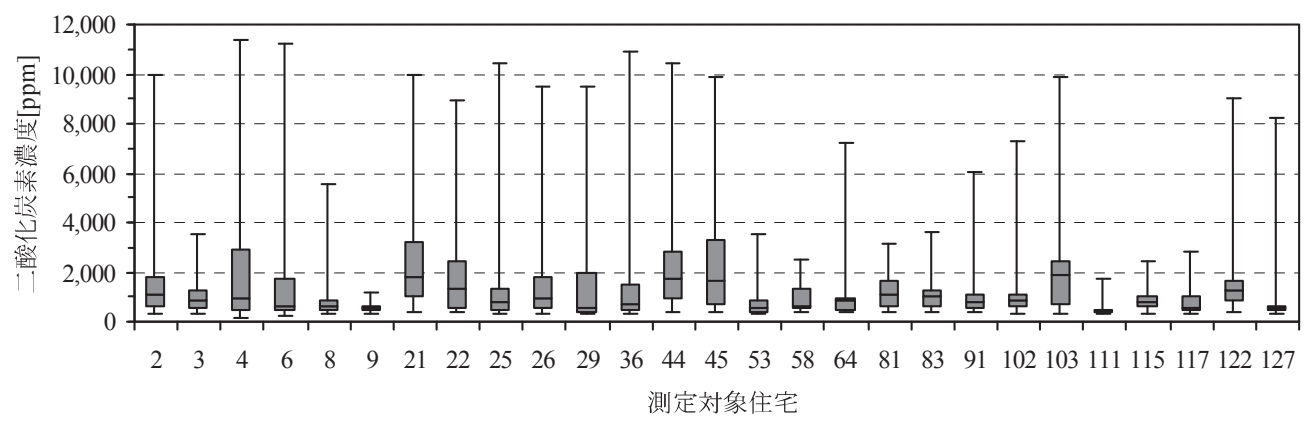

図 3 室内二酸化炭素濃度（2011 年 8 月 11 月）

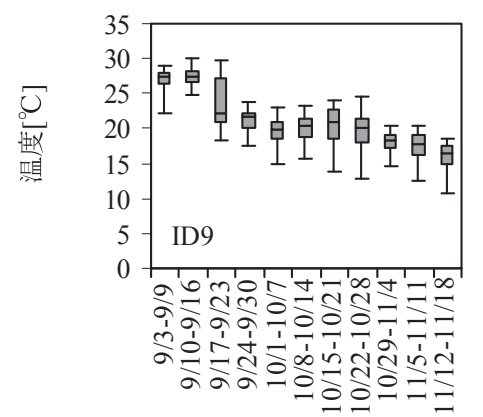

図 4 室内温度（左）と二酸化炭素濃度（右）の週間推移の例（ID9）
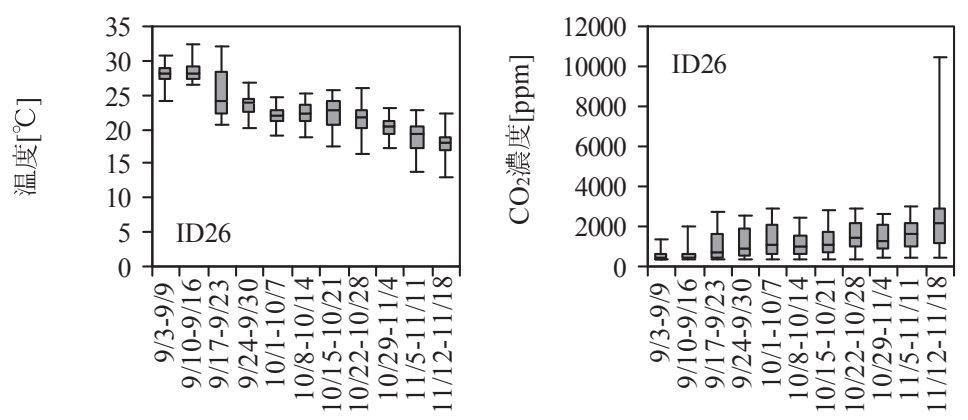

図 5 室内温度（左）と二酸化炭素濃度（右）の週閒推移の例（ID26）

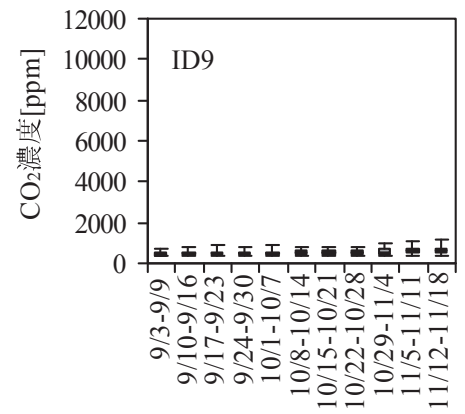

(n)



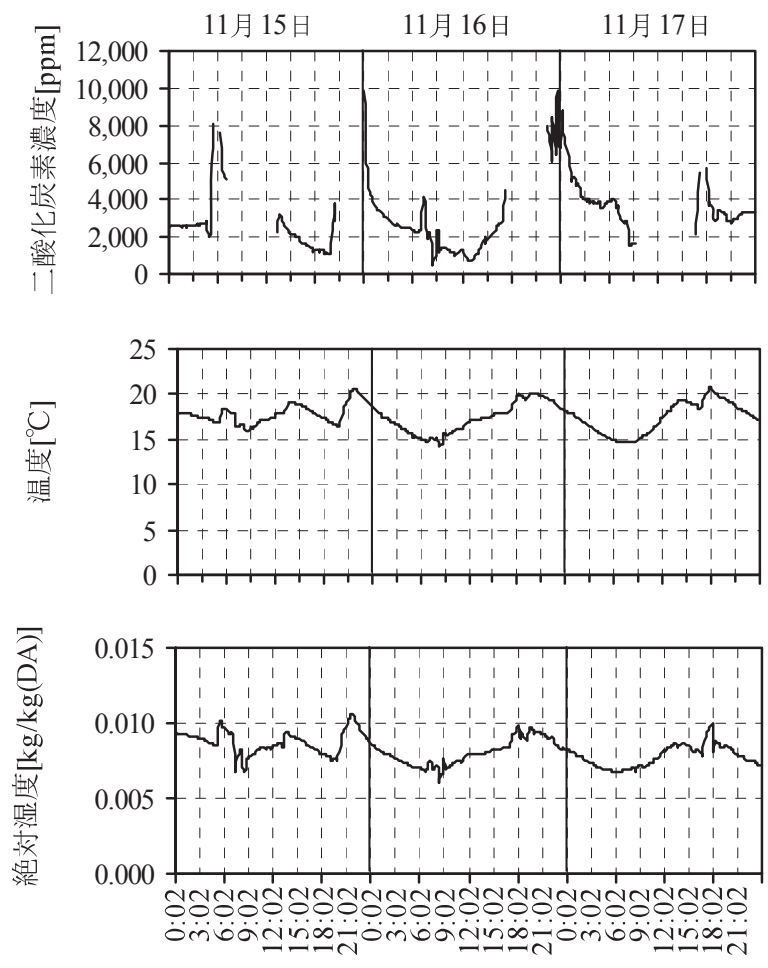

図 6 二酸化炭素濃度・温湿度の経時変化の例（ID26）

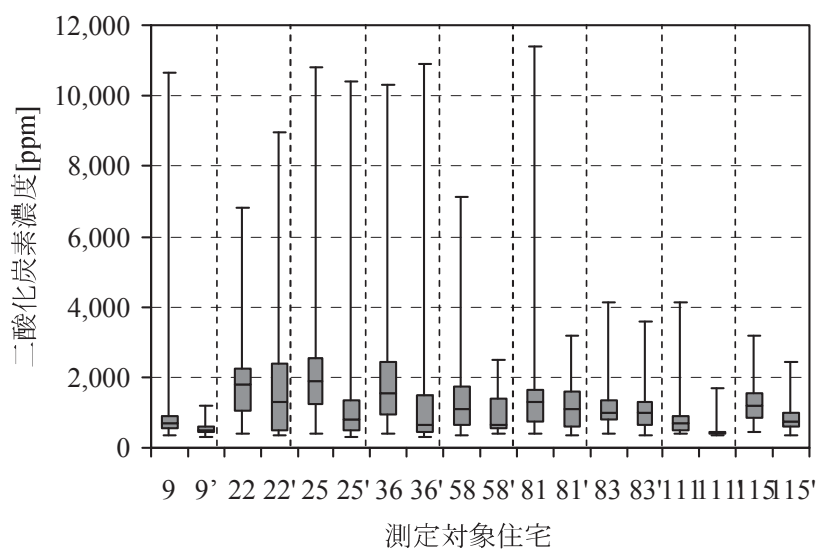

図 7 二酸化炭素濃度の測定結果

った。この濃度の上昇は換気量が不足しているためであると考えら れる。

\section{4 考察}

前述した通り，仮設住宅内の二酸化炭素濃度が高くなっているの は開放型燃焼器具が使用されたことに起因するものであると考えら れる。ここでは室内二酸化炭素濃度について試算してみる。

図 6 に示寸 ID26 宅は 2DK であり, 延べ床面積は $29.7 \mathrm{~m}^{2}$, 天井高 は $2.4 \mathrm{~m}$ である。ここで二酸化炭素の発生量を $0.131 \mathrm{~m}^{3} / \mathrm{h}$ (燃焼器具

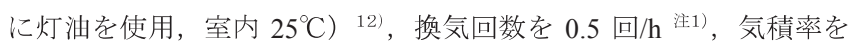
$80 \%$ と仮定したとき, 完全混合・定常状態での室内二酸化炭素濃度 は下記試算の通りで約 4,600ppm 高まることになる。この試算結果 には諸仮定が含まれているが，図 6 に示す実測值と概ね一致する。 室内濃度上昇分 $=$ 発生量/換気量
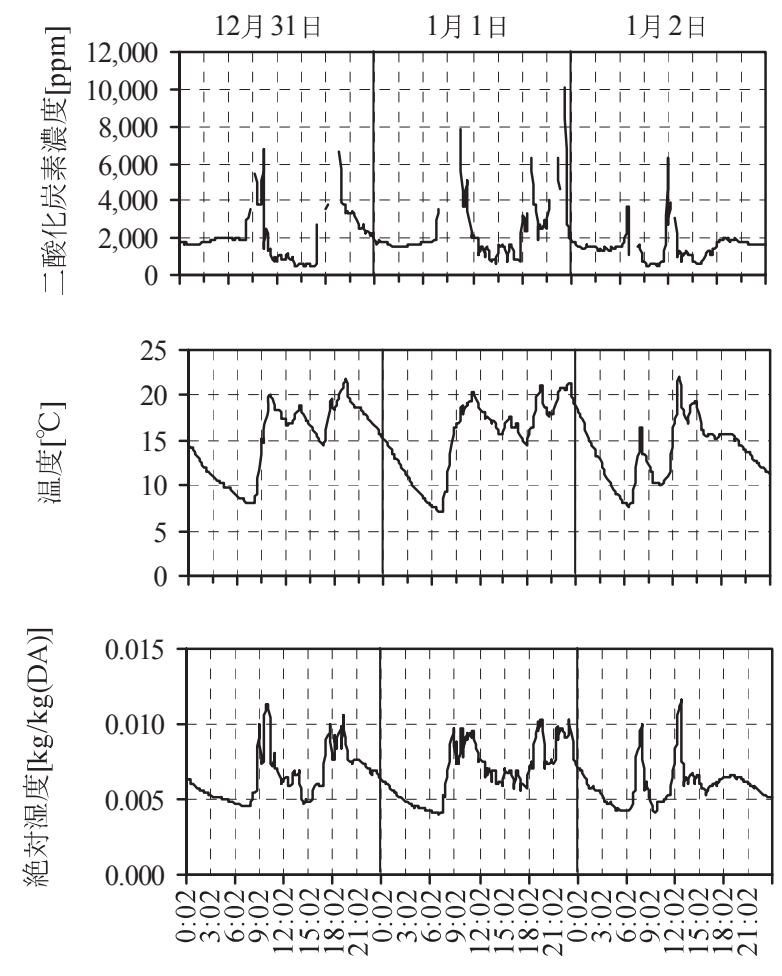

図 8 二酸化炭素濃度・温湿度の経時変化の例（ID9）

$=\left(0.131 \times 10^{6}\right) \div(29.7 \times 2.4 \times 0.5 \times 0.8)=4,595 \mathrm{ppm} \doteqdot 4,600 \mathrm{ppm}$

なお, 図 6 中の $8,000 \mathrm{ppm}$ 超えのピーク濃度は開放型ストーブの 立ち上げ時の燃焼生成物によるものと推察される。しかし，仮に換 気扇による換気を積極的に行う場合, 先述した定格風量総量の半分 であったとしても 4.3 回/h 換気量が得られ, 約 $530 \mathrm{ppm}$ しか上昇し ないことが推測される。一方, 宮城県内の一般住宅の延べ床面積 $100 \mathrm{~m}^{2}$ (平成 20 年における宮城県 1 住宅当たりの延べ面積平均值 ${ }^{13)}$ ) の条件で計算すると, 同様な住まい方であっても室内二酸化炭素濃 度の上昇が $1,365 \mathrm{ppm}$ にとどまることが分かる。ちなみに，これま でに一般住宅内の二酸化炭素濃度の測定值は数百 $\mathrm{ppm} \sim 3,000 \mathrm{ppm}$ であると報告されており 14 15), 一般住宅に比べ, 仮設住宅内では換 気を積極的に行わないと, 室内二酸化炭素濃度が非常に高くなる場 合があることが明らかになった。

室内污染物質濃度は, 定常状態であれば室の気積に関係しないが, 非定常状態であれば気積の小さい至内では室内污染物質が放出され た後の短い時間で高くなることがある。図 6 と図 8 ではピーク濃度 に達するのに 10 分程度しか要しなかった。従って, 以上の結果から

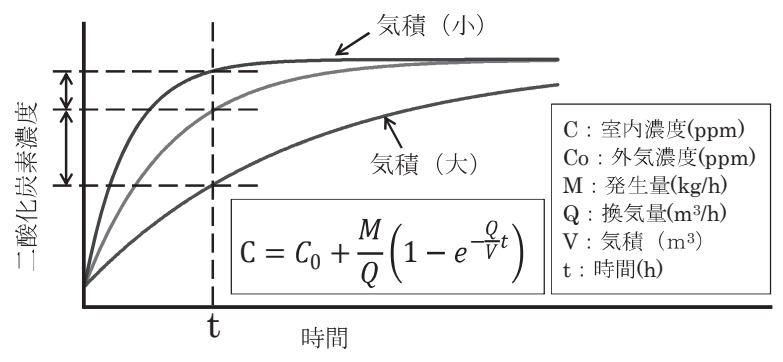

図 9 気積の違いによる二酸化炭素濃度の上昇のしかた 
気積の小さい仮設住宅でこれまでと同様な住まい方をすると，室内 二酸化炭素濃度が非常に高くなることが示唆された（図 9)。

室内二酸化炭素濃度の低減に換気が有効であることは周知の通り である。台所, 浴室, トイレの全ての換気扇が終日運転している夏 期の住宅 ID9 の室内二酸化炭素濃度が全体的には $1,000 \mathrm{ppm}$ 以下に 抑えられていることが分かる（図 3)。しかし，冬期の同住宅では換 気によって総じて二酸化炭素濃度は高くないが（75\%タイル值： 900ppm), 開放型燃焼器具が使用されたと思われる時間帯では室内 二酸化炭素濃度が 10,000ppm に達したことがあり（図 8), 換気を積 極的に行われない場合, 気積が小さいだけに, 燃焼器具を使用した 時の室内空気質の問題が存在することが窥がえた。

\section{5 まとめ}

本研究ではこれまであまり研究されてこなかった仮設住宅内の空 気環境の実態について, 宮城県内にある 27 の仮設住宅の夏期および そのうち 9 件の冬期における室内空気污染指標である二酸化炭素濃 度の詳細な測定を行い，以下に示寸事柄が明らかになった。

(1) 2011 年夏期の測定結果では仮設住宅内の二酸化炭素濃度が総じ て高く, 中央值と $75 \%$ タイル值が 1,000ppm を上回ったのはそれ ぞれ 7 件 (26\%) と 20 件（74\%）であった。また，最大值（10 分間值）が 5,000ppm を超えたのは 17 件（63\%）であり，もっと も高かったのは約 11,000ppm であった。

(2) 2012 年冬期の測定結果では, 室内二酸化炭素濃度の中央值と $75 \%$ タイル值の全て，9 件のうち 7 件の最大值はそれぞれ夏期の 室内二酸化炭素濃度の中央值, $75 \%$ タイル值，最大值を上回って おり，仮設住宅内の二酸化炭素による污染の問題が認められた。

(3) 室内二酸化炭素濃度が高くなっているのは換気が積極的に行わ れていないほか, 開放型燃焼器具の使用や, 仮設住宅の気積が小 さいなどのためであると考えられる。

(4) 換気が室内二酸化炭素濃度の低下に有効であり, 本調榃対象の住 宅のなかでも，台所・浴室・トイレの換気扇を終日運転させる ID9 宅の夏期の室内二酸化炭素濃度は 1,000ppm 以下に抑えられ ていることが明らかになった。

\section{注}

注 1) 仮設住宅の換気量は, 居住者の住まいうによって大きく異なるものと 考えられる。本論文の試算に用いた換気回数 0.5 回 $/ \mathrm{h}$ は, 篠原らの仮 設住宅における換気回数の測定結果を参考にしたものである ${ }^{16)}$ 。篠原 の测定結果では，未入居の仮設住宅（空室）の換気回数は平均で 0.25 回 $/ \mathrm{h}$, 居住後の換気回数の平均で 1.0 回 $/ \mathrm{h}$ （空明け行為のあった場合） であった。

\section{本研究に関連する既発表論文}

*1) 柳 宇, 吉野博, 長谷川兼一, 東賢一, 大澤元毅, 鍵直樹, 浜田健佑, 猪野环也, 角間隆之, 石岡沙保里：震災関連住宅における温熱・空気環 境に関する調查 第 8 報 仙台市内の応急仮設住宅に抢ける室内二酸化炭 素浱度の測定結果, シンポジウム「東日本大震災からの教訓, これから の新しい国つくり」論文集，pp.369-372，2012

*2) 柳宇, 吉野博, 長谷川兼一: 仮設住宅に㧍ける室内空気質の実態, シン ポジウム：東日本大震災に学ぶこれからの環境工学, pp.65-72, 2012

\section{参考文献}

1）山岡耕春 : 東日本大震苂とこれからの備え, 平成 23 年度空気調和・衛 生工学会公開講演会資料, p.11，2011

2)「震災発 DATE 阪神・淡路大震災」http://www.shinsaihatsu.com/data/ kasetsu hoka.html，閲覽日：2012.8.11

3)例えば, 五十嵐由利子, 萬羽郁子：新潟県中越地震における応急仮設 住宅の温熱環境, Proc. of The $30^{\text {th }}$ Symposium on human-Environment System HES In Yokohama, 1-3, December, pp.89-92, 2006

4) 吉野博, 長谷川兼一，柳宇：震災関連住宅における温熱・空気環境に 関する調査 第 1 報 応急仮設住宅の特徵と簡易アンケート調査結果, シンポジウム「東日本大震災からの教訓, これからの新しい国つくり」 論文集，pp.341-344，2012

5) 浜田健佑, 吉野博, 長谷川兼一, 柳 宇, 東賢一, 猪野玩也, 角間 隆 之：震災関連住宅における温熱・空気環境に関する調査 第 2 報 応急 仮設住宅の居住環境と健康に関する夏期アンケート調查の単純集計結 果, シンポジウム「東日本大震災からの教訓, これからの新しい国つ くり」論文集, pp.345-348, 2012

6）大澤元毅，吉野博，長谷川兼一，柳 宇，東賢一，鍵直樹，浜田健佑， 猪野㙇也，角間隆之：震災関連住宅における温熱・空気環境に関する 調查 第 3 報 宮城県応急仮設住宅における聞き取り調査の結果：シン ポジウム「東日本大震災からの教訓, これからの新しい国つくり」論 文集，pp.349-352，2012

7) 長谷川兼一, 吉野博, 柳 宇, 東賢一, 大澤元毅, 鍵直樹, 浜田健佑, 猪野玩也，角間隆之：震災関連住宅における温熱・空気環境に関する 調查 第 6 報 温熱環境の調查結果(1) 仙台市内の応急仮設住宅を対 象とした夏期・秋期の実測調査結果，シンポジウム「東日本大震災か らの教訓，これからの新しい国つくり」論文集，pp.361-364，2012

8) 石岡沙保里, 吉野博, 柳 宇, 長谷川兼一, 東賢一, 大澤元毅, 鍵直 樹，浜田健佑，猪野玩也，角間隆之：震災関連住宅における温熱・空 気環境に関する調査. 第 9 報 仙台市内の応急仮設住宅における室内真 菌の测定絬果，シンポジウム「束日本大震災からの教訓，これからの 新しい国つくり」論文集，pp.373-376，2012

9）鍵直樹，吉野博，長谷川兼一，柳 宇，東賢一，大澤元毅，本間義規， 浜田健佑，猪野玩也，角間隆之：震災関連住宅における温熱・空気環 境に関する調査 第 10 報 応急仮設住宅室内における揮発性有機化合 物の調査結果，シンポジウム「東日本大震災からの教訓，これからの 新しい国つくり」論文集, pp.377-380, 2012

10）柳宇, 吉野博, 長谷川兼一, 東賢一, 大澤元毅, 鍵直樹, 浜田健佑, 猪野玩也，角間隆之，石岡沙保里：震災関連住宅における温熱・空気 環境に関する調查 第 8 報 仙台市内の応急仮設住宅における室内二酸 化炭素濃度の测定結果, シンポジウム「東日本大震災からの教訓, こ れからの新しい国つくり」論文集，pp.369-372，2012

11) ISO $16000-26$ : Indoor air-Part 26 : Sampling strategy for carbon dioxide $\left(\mathrm{CO}_{2}\right)$, First edition, 2012-08-01

12）空気調和・衛生工学会：空気調和・衛生工学会規格一換気規準・同解 説, SHASE-S 102-2011, p.37, 2012

13）総務省統計局：「平成 20 年住宅 - 上地統計調查表番号 15 」 http://www.e-stat.go.jp/SG1/estat/List.do?bid=000001029530\&cycode $=0$, 閲 覧日：2013.3.21

14）岩崎有喜：シックハウス対策と二酸化炭素濃度に関する考察，岩手県 立産業技術短期大学校紀要，第 9 号, pp.29-32，2009

15) 松永潤一郎，その他 3 名：湿度により排気利用を制御寸る第 3 種換気 システムの換気性能評価一その 3 夏期における換気システム消費電力お よび二酸化炭素濃度測定結果, 日本建築学会大会学術講演梗概集, 環 境工学 II, pp.687-688, 2005

16）篠原直秀, 柳宇, 徳村雅弘, 水越厚史, 吉野博 : 震災関連住宅におけ る温熱・空気環境に関する調査 第 18 報 南相馬市における応急仮設 住宅の室内空気質, 日本建築学会大会学術講演梗概集環境工学 I, pp.1059-1060, 2012 